Tamás Makkai, János Kundrák, Miskolc, Hungary, Nikolaos E. Karkalos, Angelos P. Markopoulos, Athens, Greece

\title{
FACE MILLING WITH A ROUND INSERT AT VARIOUS CUTTING SPEEDS AND FEED RATES
}

\begin{abstract}
Face milling is frequently used for the rendering of flat surfaces with a high degree of precision. With this machining process, high material removal rate is possible to be attained but management of cutting forces values is also desirable, in order to avoid excessive power consumption, tool wear or vibrations. This can be achieved by selecting the process parameters within an appropriate range for each case. In the present study, an experimental investigation is conducted with a view to determine the effect of two important process parameters, namely cutting speed and feed on the cutting forces and the specific cutting forces during face milling, in cases where a round insert is used.
\end{abstract}

Keywords: face milling; cutting speed; feed rate; round insert; cutting forces; specific cutting forces.

\section{INTRODUCTION}

Face milling is among the most important machining operations and one of the most popular as well, due to its high degree of versatility, emerging from the capabilities of using a large variety of cutting inserts at different process conditions. During face milling, parts with flat surfaces perpendicular to the milling head axis are machined, with a view to remove a desired amount of bulk material or improve surface quality and dimensional accuracy. Thus, it is preferred to be employed in a large variety of industrial applications in the automotive and aerospace industries. In order to maintain the integrity of machined surfaces, it is desirable to control the cutting forces so as not to exceed the limits which lead to low levels of damage, lower energy consumption, higher tool life and fewer vibrations. In order to be able to control the process outcome for given process parameters, it is preferable to conduct experimental and numerical studies [1,2].

In the previous research works, the influence of process conditions such as feed rate, cutting speed and chip cross-section shape on cutting forces were investigated $[3,4]$ and it was shown that the feed rate plays a more important role in cases with the use of common rectangular inserts. Thus, in the present study, the influence of these parameters in cases of face milling with the use of a round insert will be investigated. In the relevant literature, there were reported various cases where round cutting inserts are employed both in turning and milling processes. Regarding milling, it is reported that round 
cutting inserts have several peculiarities due to their shape, e.g. the entering angle is a function of the axial depth of cut [5], they can spread the force and heat distributions more evenly, reducing the cutting edge wear and increasing surface quality. Furthermore, it is observed that the chip thickness distribution along the cutting edge, varies along this edge [6]. For milling with a round cutter it is stated that the depth of cut should be less than $2 / 3$ or the insert radius in order to avoid vibrations [7] and that the cutting edge angle varies with the axial depth of cut [8].

Antonialli et al. [5] conducted experiments with a view to reduce vibrations during face milling of a titanium alloy by using tools with low entering angles. More specifically, they employed cutters with square and round inserts. Their findings indicated that for the round insert, higher frequencies were detected when analyzing the cutting force signal due to the specific shape of the chip, which has a comma-like shape in the rake face of the tool. This shape was associated with severe friction between the tool and workpiece, as in this case, a part of the chip has always a thickness equal to zero regardless of the instantaneous angle of the feed direction leading to vibrations, and shorter tool life. Euan et al. [9] developed an analytical model for the modeling of both static and dynamic cutting forces during milling, with round geometry inserts, in order to determine the optimum process parameters. They stated that previous analytical models did not account for the dynamic part of the forces. Their findings showed that the model was accurate enough for the study of face-milling with round inserts. Ghorbani and Moetakef-Imani [6] developed also a mechanistic model of cutting forces for cases of face milling with round inserts, for which improved models need to be used due to the complex geometry. In their model, calculation of specific cutting force coefficients was performed with the aid of Non-dominated Sorting Genetic Algorithm II (NSGA II) and artificial neural networks. This methodology was proven successful in capturing the variation of specific cutting force coefficients under various process conditions.

Gurdal et al. [8] compared the performance of various types of milling inserts for cases of rough milling. They found that the round insert exhibited relatively lower rate of deterioration, uniform flank wear, but stronger tempering effect. It was also shown that it was less sensitive to process parameters variation than the other inserts and it was suggested that high axial depths should be preferred in order to be competitive to the high-feed insert. This cutting insert was preferred for use in several special milling cutters. For example, Baro et al. [10] presented a model of cutting forces during face milling with a self-propelled milling cutter with round inserts. They stated that round inserts are common in rotary tools. The diameter of the round insert is similar to the tool nose radius of a stationary insert although usually the 
diameter of round inserts is very large compared to the tool nose radius. Furthermore, in their investigation of the appropriate orientation of a torus milling cutter, Gilles et al. [7] used round inserts, as they stated that this type of cutting insert has significant advantages over the other insert types.

Tapoglou and Antoniadis [11] presented a comprehensive model based on $\mathrm{CAD}$ and analytical models in order to predict surface topography and cutting forces during face milling with various milling strategies and insert types, among them round inserts. Denkena et al. [12] presented models for hard milling with modified cutting inserts with special undercut geometry in order to assess their influence on hard milling outcome. Qing Zhang et al. [13] performed FEM simulations for hard milling of AISI H13 steel with a round cutting insert. In their work, only the cutting edge was modeled and they were able to predict cutting forces and temperature for various cases with considerable accuracy. In their work, Felhő and Kundrák [14] compared the performance of octagonal and circular cutting inserts and found that the circular cutting insert produced significantly lower surface roughness during face milling for the same cases.

In the present paper, the effect of two main process parameters, namely feed rate and cutting speed on the cutting forces and specific cutting forces during face milling with round inserts will be investigated in order to be able to choose the suitable values of these process parameters which can lead to the achievement of adequate material removal rate without excessive deterioration of workpiece integrity and tool life.

\section{METHODOLOGY}

In the present work, face milling experiments with a milling head with a single round cutting insert (Figure 1) were performed in a Perfect Jet MCV-M8 vertical machining centre. The milling head was a Sandvik CoroMill R200068Q27-12L face milling head with a diameter $\left(D_{s}\right)$ of $68 \mathrm{~mm}$ while the cutting insert was a Sandvik Coromant RCKT1204M0-PM FC4230 coated carbide insert.

The face milling experiments were conducted on normalized $\mathrm{C} 45$ (1.0503) carbon steel workpieces with hardness of HB180, cutting width 58 $\mathrm{mm}$ and cutting length $50 \mathrm{~mm}$. The experiments were conducted in two series; in the first one, the depth of cut and cutting speed were kept constant at $0.8 \mathrm{~mm}$ and $200 \mathrm{~m} / \mathrm{min}$ respectively and the feed per tooth was varied in the range of $0.1-0.8 \mathrm{~mm} /$ tooth, namely $0.1,0.2,0.3,0.4,0.8 \mathrm{~mm} /$ tooth whereas in the second series of experiments, the depth of cut and feed per tooth values were kept constant at $0.8 \mathrm{~mm}$ and $0.4 \mathrm{~mm} /$ tooth respectively and the cutting speed was varied in the range of 100-500 $\mathrm{m} / \mathrm{min}$, namely $100,200,300,400$ and 500 $\mathrm{m} / \mathrm{min}$. All experiments were conducted under dry machining conditions. 
During the experiments, the three components of cutting force were recorded using a Kistler 9257A dynamometer and the measured signals were amplified by using three Kistler 5011A charge amplifiers for signals corresponding to each component of the cutting force. Finally, the amplified signals were processed through a CompactDAQ-9171 data collector with 4 channels and recorded in a laptop using specialized measurement software, prepared by Labview programming language. It is to be noted that cutting forces are measured in a coordinate system (xyz) defined on the workpiece rather than the cutting tool.

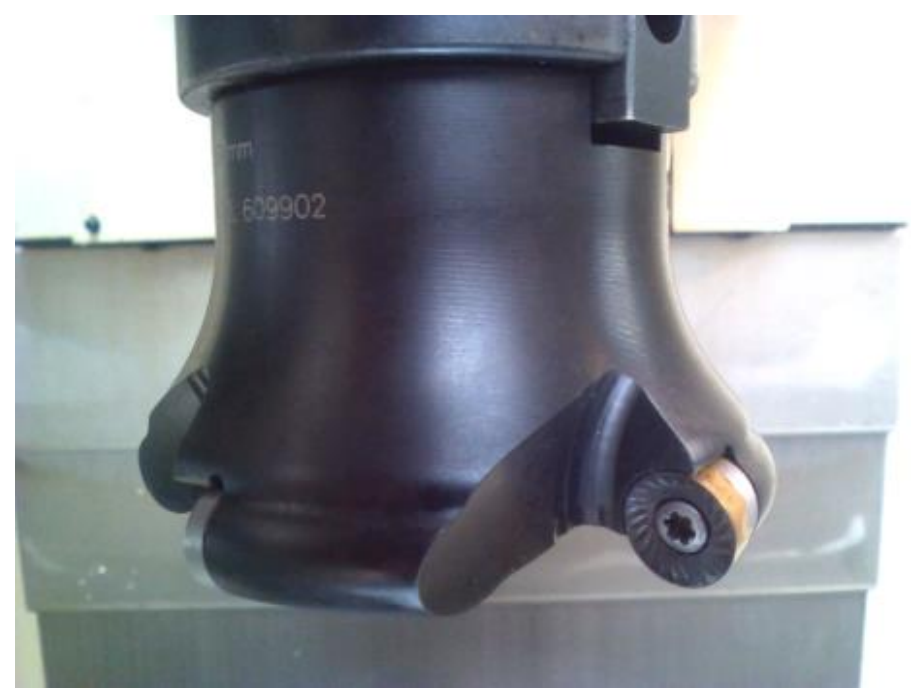

Figure 1 - The applied milling head with one round insert

\section{RESULTS AND DISCUSSION}

After the completion of experiments, the evolution of cutting forces during the experiments is analyzed in order to determine the influence and relative importance of feed rate and cutting speed regarding cutting forces and special cutting forces. In every case, the maximum cutting forces are used in the figures and the calculations.

Regarding the results from the first set of experiments, it can be seen at first from Figure 2, that, increasing feed rate results clearly to an increase of every component of cutting force, as anticipated due to the increase of the engagement between cutting tool and workpiece. 


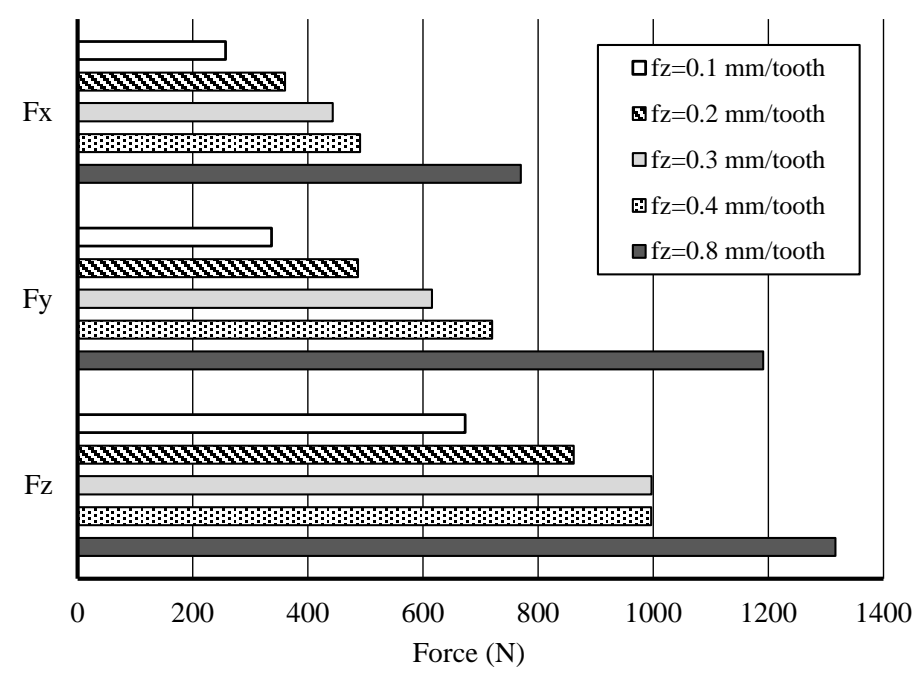

Figure 2 - Variation of cutting force components at different feed rate values $\left(a_{p}=0.8 \mathrm{~mm}, v_{c}=200 \mathrm{~m} / \mathrm{min}\right)$

It is noteworthy that cutting forces values are considerably higher in all cases in the z-axis, especially at low feed rate values, followed by the $F_{y}$ and $F_{x}$ values. However, the influence of feed rate is not the same for each cutting force component; as can be seen from Figure 2, the highest increase between cases with the lowest and highest feed rate values is observed for the y-axis component of cutting forces and the lowest one for the $\mathrm{z}$-axis component of cutting forces. More specifically, the maximum cutting force between cases with the highest and lowest value of feed rate, for an 8 -fold increase of its value, in the $\mathrm{x}$-axis was increased by almost 3 times, in the $\mathrm{y}$-axis it was increased by almost 3.5 times and in the z-axis almost 2 times. Regarding the results from the second set of experiments, it can be clearly seen that an increase of cutting speed results in a decrease of $F_{x}$ and $F_{y}$ components of cutting force whereas it results in an increase of $F_{z}$ component of cutting force. The observed trend for $F_{x}$ and $F_{y}$ cutting forces in Figure 3 can be attributed to increased cutting temperature, which causes softening of the workpiece material.

As in the case of varying feed rate, $F_{z}$ values are larger in each case, followed by $F_{y}$ and $F_{x}$ values. However, with varying cutting speed values, it was found that $F_{x}$ values are influenced to greater extend whereas $F_{y}$ values are 
considerably less affected and $\mathrm{F}_{\mathrm{z}}$ values are inversely affected, as it was aforementioned. More specifically, a 5-fold increase of cutting speed values results in a decrease of $F_{x}$ of 1.4 times and a decrease of $F_{y}$ of 1.12 times, whereas $\mathrm{F}_{\mathrm{z}}$ is increased by 1.16 times. Consequently, it can be deduced that feed rate has a more important effect on cutting force results, as for an 8 -fold increase compared to a 5 -fold for cutting speed, it resulted in a relatively higher change of cutting force component values.

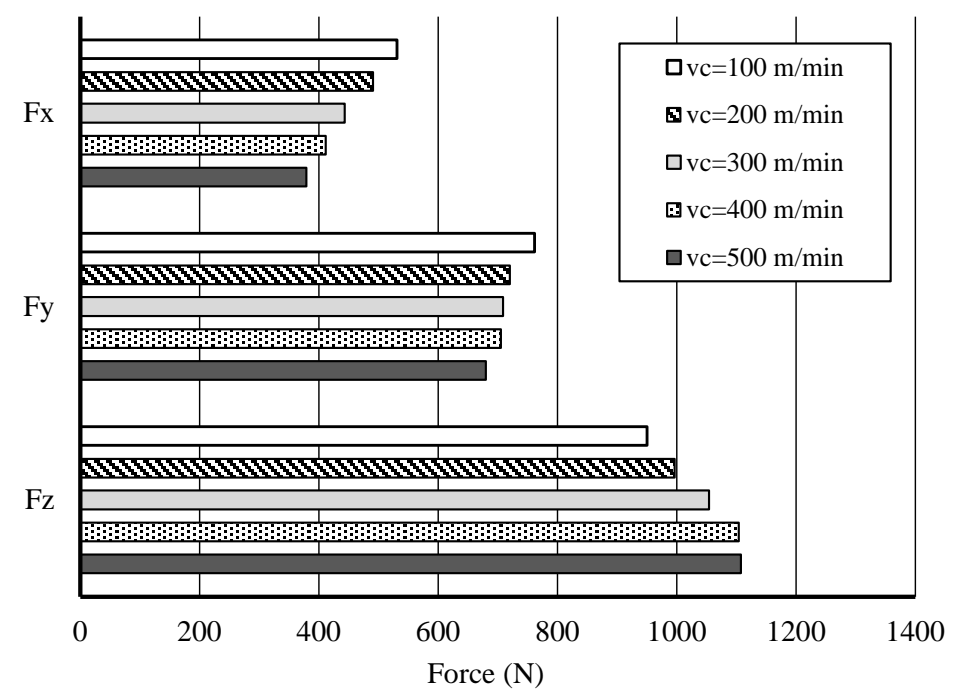

Figure 3 - Variation of cutting force components at different cutting speed values $\left(\mathrm{a}_{\mathrm{p}}=0.8 \mathrm{~mm}, \mathrm{f}_{\mathrm{z}}=0.4 \mathrm{~mm} / \mathrm{tooth}\right)$

Furthermore, the specific cutting force components were also calculated in each case and subsequently analyzed. It is to note that specific cutting forces are calculated as the ratio of cutting force components to the chip cross-section value. In the case of cutting speed values, the chip cross-section value does not change so the trends of specific cutting force components are exactly the same with the respective cutting force components, as can be seen in Figure 4.

However, in the case of feed rate variation, the chip cross-section value changes as well. Thus, in this case a decreasing trend of all specific cutting force components with an increase of feed rate is attested, as it is also depicted in Figure 5. 


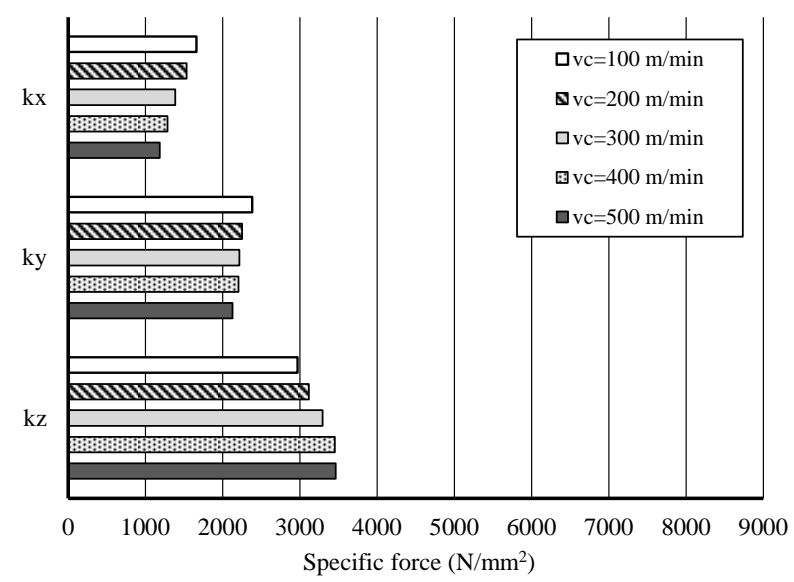

Figure 4 - Variation of specific cutting forces at different cutting speed values $\left(\mathrm{a}_{\mathrm{p}}=0.8 \mathrm{~mm}, \mathrm{f}_{\mathrm{z}}=0.4 \mathrm{~mm} /\right.$ tooth $)$

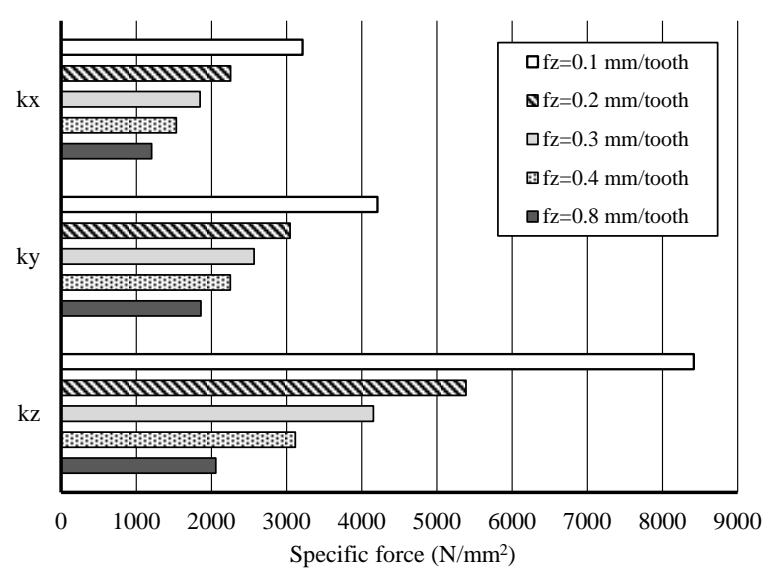

Figure 5 - Variation of specific cutting forces at different feed rate values $\left(a_{p}=0.8 \mathrm{~mm}, v_{c}=200 \mathrm{~m} / \mathrm{min}\right)$

\section{CONCLUSIONS}

In the present study, experimental work on face milling under various cutting speed and feed rate values was carried out, using a milling head with a single round milling insert. After the analysis of the experimental results 
regarding cutting forces and specific cutting forces, various conclusions can be drawn:

In the first set of experiments, with a variable cutting speed, an increase of cutting speed caused a decrease of cutting force components due to higher cutting temperature and softening of the material workpiece, whereas in the second set of experiments, with variable feed rate, an increase in feed rate caused a clear increase of cutting force values as a more intense engagement of the cutting tool and the workpiece occurs. These results are in accordance with the relevant literature, ensuring the validity of the experiments. Moreover, it was shown that the larger forces are obtained in z-axis in both sets of experiments but increase of feed rate affects mostly the $\mathrm{F}_{\mathrm{y}}$ component whereas increase of cutting speed affects most the $F_{z}$ component. Analysis of specific cutting forces revealed trends in accordance with the cutting forces results in the case of variable cutting speed, whereas the increase of feed rate had an adverse effect on specific cutting forces due to the increase of chip crosssection.

The increase of feed rate was shown to lead to larger variation of the cutting forces than the increase of cutting speed; thus, it can be concluded that regulation of cutting forces can be more effectively conducted in terms of feed rate change rather than cutting speed in order to achieve lower power consumption as well as lower workpiece damage and longer tool life.

\section{ACKNOWLEDGEMENTS}

The authors greatly appreciate the support of the National Research, Development and Innovation Office - NKFIH (No. of Agreement: K 116876). The described study was carried out as part of the EFOP-3.6.1-16-00011 "Younger and Renewing University - Innovative Knowledge City institutional development of the University of Miskolc aiming at intelligent specialization" project implemented in the framework of the Szechenyi 2020 program.

Both supports are gratefully acknowledged.

References: 1. Borysenko, D., Karpuschewski, B., Wenzel, F., Kundrák, J., Felhö, C.: Influence of cutting ratio and tool macro geometry on process characteristics and workpiece conditions in face milling, CIRP Journal of Manufacturing Science and Technology 24, pp. 1-5. (2019). 2. Karpuschewski, B., Kundrák, J., Felhö, C., Varga, G., Sztankovics, I., Makkai, T.: Preliminary investigations for the effect of cutting tool edge geometry in high-feed face milling, Vehicle and Automotive Engineering 2, pp. 241-254. (2018). 3. Kundrák, J., Markopoulos, A. P., Makkai, T., Deszpoth, I., Nagy, A.: Analysis of the effect of feed on chip size ratio and cutting forces in face milling for various cutting speeds, Manufacturing Technology 18(3), pp. 431-438. (2018). 4. Kundrák, J., Gyáni, K., Felhö, C., Deszpoth, I.: The effect of the shape of chip cross section on cutting force and roughness when increasing feed in face milling, Manufacturing Technology 17(3), pp. 335-342. (2017). 5. Antonialli, A. I. S., Diniz, A. E., Pederiva, R.: Vibration analysis of cutting force in titanium alloy milling, International Journal of Machine Tools and Manufacture 50(1), pp. 65-74. (2010). 6. Ghorbani, H., Moetakef-Imani, B.: Specific cutting force and cutting condition 
interaction modeling for round insert face milling operation, International Journal of Advanced Manufacturing Technology 84(5-8), pp. 1705-1715. (2016). 7. Gilles, P., Monies, F., Rubio, W.: Optimum orientation of a torus milling cutter: method to balance the transversal cutting force, International Journal of Machine Tools and Manufacture 47(15), pp. 2263-2272. (2007). 8. Gurdal, O., Wright, A., Carpenter, C., Blackmore, M.: Investigation of the performance of different face milling inserts to improve rough milling of SA508 grade 3 forgings, ASME 2018 Pressure Vessels and Piping Conference, Prague (2018). 9. Euan, I. G., Ozturk, E., Sims, N. D.: Modeling static and dynamic cutting forces and vibrations for inserted ceramic milling tools, Procedia CIRP 8, pp. 564569. (2013). 10. Baro, P. K., Joshi, S. S., Kapoor, S. G.: Modeling of cutting forces in a facemilling operation with self-propelled round insert milling cutter, International Journal of Machine Tools and Manufacture 45(7-8), pp. 831-839. (2005). 11. Tapoglou, N., Antoniadis, A.: 3Dimensional kinematics simulation of face milling, Measurement 45(6), pp. 1396-1405. (2012). 12. Denkena, B., Kohler, J., Bergmann, B.: Development of cutting edge geometries for hard milling operations, CIRP Journal of Manufacturing Science and Technology 8, pp. 43-52. (2015). 13. Zhang, $Q$., Zhang, S., Li, J.: Three dimensional finite element simulation of cutting forces and cutting temperature in hard milling of AISI H13 steel, Procedia Manufacturing 10, pp. 37-47. (2017). 14. Felhö, C., Kundrák, J.: Comparison of Theoretical and Real Surface Roughness in face milling with octagonal and circular inserts, Key Engineering Materials 581, pp. 360-365. (2014).

\title{
Тамаш Макай, Янош Кундрак, Мішкольц, Угорщина, Ніколаос Е. Каркалос, Ангелос П. Маркопулос, Афіни, Греція \\ ТОРЦЕВЕ ФРЕЗЕРУВАННЯ КРУГЛОЮ ПЛАСТИНОЮ ПРИ РІЗНИХ ШВИДКОСТЯХ РІЗАННЯ І ПОДАЧІ
}

\begin{abstract}
Анотація. Ториеве фрезерування часто використовується для отримання плоских поверхонь з високим ступенем точності. За допомогою изого процесу обробки можна досягти високої швидкості видалення матеріалу, але також бажано мати можливість управління значеннями сил різання, щзоб уникнути надмірного споживання енергії, зносу інструменту або вібрацій. Це може бути досягнуто шляхом вибору параметрів процесу у відповідному діапазоні для кожного випадку. У иьому дослідженні експеримент проводиться з метою визначення впливу двох важливих параметрів прочесу, а саме швидкості різання $i$ подачі на сили різання $і$ питомі сили різання під час ториевого фрезерування, у випадках, коли використовується одна кругла пластина. Після аналізу експериментальних результатів, що стосуються сил різання і питомих сил різання, можна зробити різні висновки. У першій серії експериментів зі змінною швидкістю різання, збільшення швидкості різання викликало зменшення компонентів сили різання через більш високі температури різання і розм'якшення заготовки матеріалу, тоді як у другій серії експериментів зі змінною швидкістю подачі, збільшення швидкості подачі викликало явне збільшення значень сили різання при більш інтенсивному зачепленні ріжучого інструменту $i$ заготовки. Ці результати узгоджуються з відповідною літературою, що забезпечує достовірність експериментів. Аналіз питомих сил різання виявив тенденції відповідно до результуючих сил різання в разі змінної швидкості різання, тоді як збільшення швидкості подачі зробило несприятливий вплив на питомі сили різання через збільшення поперечного перерізу стружки. Було показано, що збільшення швидкості подачі призводить до більшої зміни сил різання, ніж збільшення швидкості різання. Таким чином, можна зробити висновок, що регулювання сил різання може бути більш ефективно проведено з точки зору зміни швидкості подачі, а не швидкості різання, для досягнення більи низького енергоспоживання, а також меншого пошкодження заготовки $i$ збільшення терміну служби інструменту.
\end{abstract}

Ключові слова: ториеве фрезерування; швидкість різання; швидкість подачі; кругла пластина; сили різання; питомі сили різання. 